\title{
Analysis of Determining Target Accuracy of Rocket Launchers on Xbee-Pro based Wheeled Robots to Realize the Development of Technology on the Military Field
}

\author{
Anggara Trisna Nugraha, Dadang Priyambodo \\ Marine Electrical Engineering Shipbuilding Institute of Polytechnic Surabaya, Surabaya \\ Jl. Teknik Kimia Keputih Sukolilo, Surabaya 60111, Indonesia
}

\section{Article Info \\ Article History: \\ Received Sept 15, 2020 \\ Revised Sept 30, 2020 \\ Accepted Oct 21, 2020}

\section{Keywords:}

Wheel Robot

Rocket launcher

Angle Position

Xbee-pro

\begin{abstract}
At this time the rocket launcher is still controlled by humans who utilize technology using a PC and a servo motor as a control device to determine the accuracy at the shooting angle, in designing this robot complete components are needed so that the robot can work automatically according to the input given, the rocket launcher robot controlled automatically by communication from the PC after which the command is forwarded to the microcontroller using a USB TTL cable and sent to the Xbee-pro sender circuit then transmitted and received by the Xbee-pro receiver then transmitted to the microcontroller and processed to the control system on the launcher a rocket in the form of a servo motor and a relay as a component in the firing of the rocket launcher. Based on the test results, the robot has been able to direct the rocket launcher at a predetermined angle and has been able to carry out firing actions on each rocket starting from manual rockets, double rockets, triple rockets and full rockets with a success rate of up to $80 \%$.
\end{abstract}

\author{
The Corresponding Author: \\ Anggara Trisna Nugraha \\ anggaranugraha@ppns.ac.id, \\ Marine Electrical Engineering \\ Shipbuilding Institute of Polytechnic Surabaya \\ Jl. Teknik Kimia Keputih Sukolilo, Surabaya 60111, Indonesia
}

\section{INTRODUCTION}

In this era of technological development, the need for military equipment is growing. This need can be met through domestic production capabilities [1] - [3]. These factors are the basis for the formulation of directions, priorities, and policies for the development and mastery of defense and security technology, especially in the field of weaponry [4] - [6]. The development of science and technology in several developed countries has created robots as a means to help improve the professionalism of their soldiers. such as "MOROLIPI Bomb Disarming Robot [7]. "Application of Mobile Manipulator Model for Bomb Defusing Robot" which is used to defuse a bomb with a load of $0.5 \mathrm{~kg}$ [8].
This work is an open-access article and licensed under a Creative Commons Attribution-ShareAlike 4.0 International License (CC BY-SA 4.0).

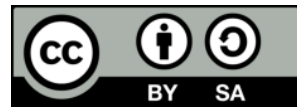

Technological advances, however, require the ability of the country's defense to be able to resist enemy attacks efficiently and effectively. One such advancement is in the field of military robotics. These military robots can be an alternative to human warriors designed to handle a wider variety of combat tasks, one of which is target acquisition with greater efficiency compared to human soldiers. They can be deployed in extremely dangerous situations and areas which reduce the chances of casualties by human troops. They are designed in various shapes and sizes with different functions. The human military will put more emphasis on developing various new robotic technologies that can help soldiers in case of war.

With this background, researchers are trying to develop by analyzing chain-wheeled robots that can be remotely controlled to carry out reconnaissance and attacks in the area of operation, 
so as to reduce personnel and material losses when performing tasks in the operation area [10].

\section{MATERIALS AND METHODS}

\section{A. Block Diagram Tool}

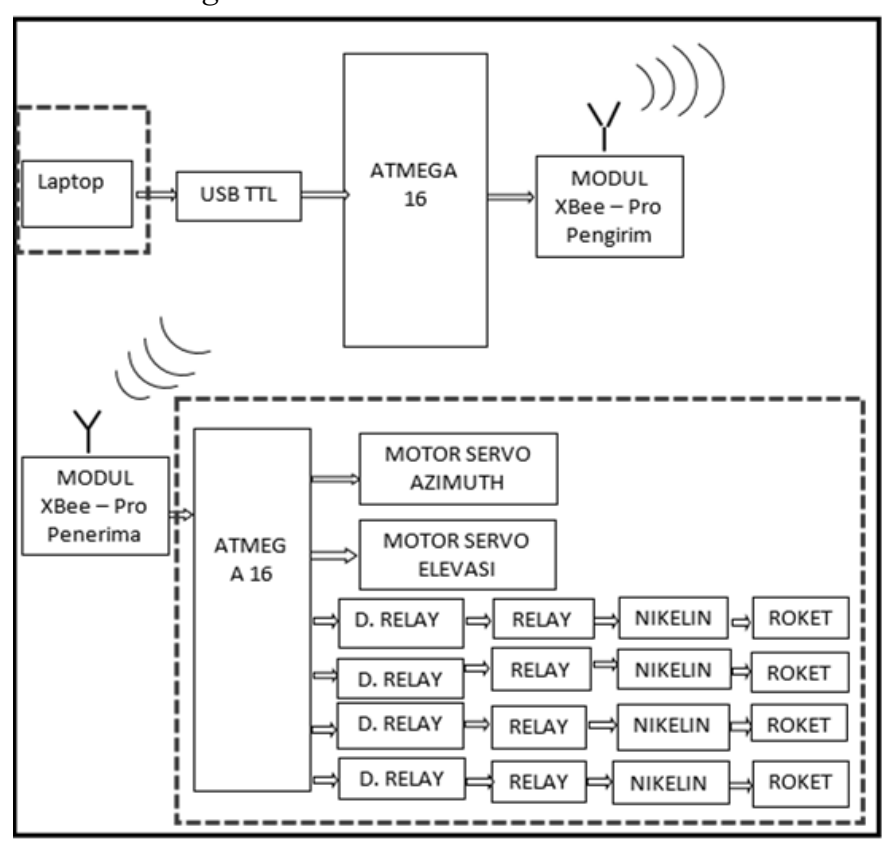

Fig. 1. Determining the Optimal Target Accuracy for a Wheeled Robot with a Rocket Launcher

Xbee-pro. This circuit works as a recipient of data sent via the sender's Xbee-pro module, the data is received and then sent to the ATMega 16 microcontroller. The voltage that enters the ATMega 16 microcontroller is converted and sent back to the servo motor to drive the elevation and azimuth motors. The data that enters the ATmega 16 microcontroller is converted and sent to the relay driver, then headed for nickel to fire at the rocket, depending on the data sent by ATMega 16.

\section{B. Mechanical Design}

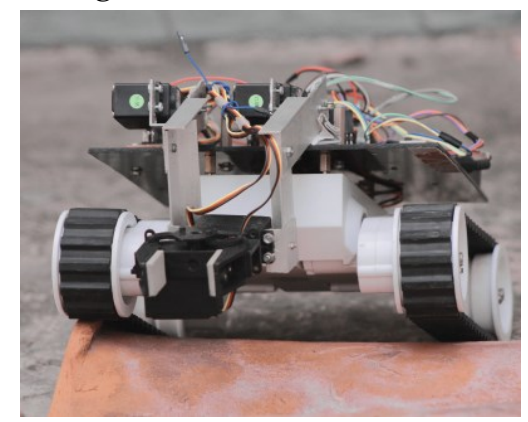

Fig. 2. Robot mechanical design

\section{Algorithm Tools}

Activating the program by turning on the power, then the process of initializing the ports that will be used in the system occurs. The microcontroller detects instruction data or commands sent from waiting for input data if "No" then returns to waiting for instructions, if "Yes" take the instruction data. The microcontroller gets data from taking the instruction data then goes to the left azimuth instruction, if "Yes" then activates the left azimuth motor and will die if the instruction has switched to another instruction or there is no instruction, if not then it enters the right azimuth instruction. The microcontroller gets data from the left azimuth instruction to the upper elevation instruction, if "Yes" then activates the upper elevation motor and will die if the instruction has switched to another instruction or there is no instruction, if "no" then enters the lower elevation instruction. The microcontroller gets data from the upper elevation instruction to the lower elevation instruction, if "Yes" then activates the lower elevation motor and will die if the instruction has switched to another instruction or there is no instruction, if "no" then goes to the instruction to activate the shot. The instruction activates fire if "Yes" then activates the relay and automatically fires the rocket using nickeline wire; if the instruction has switched to another instruction or there is no instruction, if "no" will stop the azimuth and elevation motor. If the system is deactivated, all processes on the microcontroller will stop.

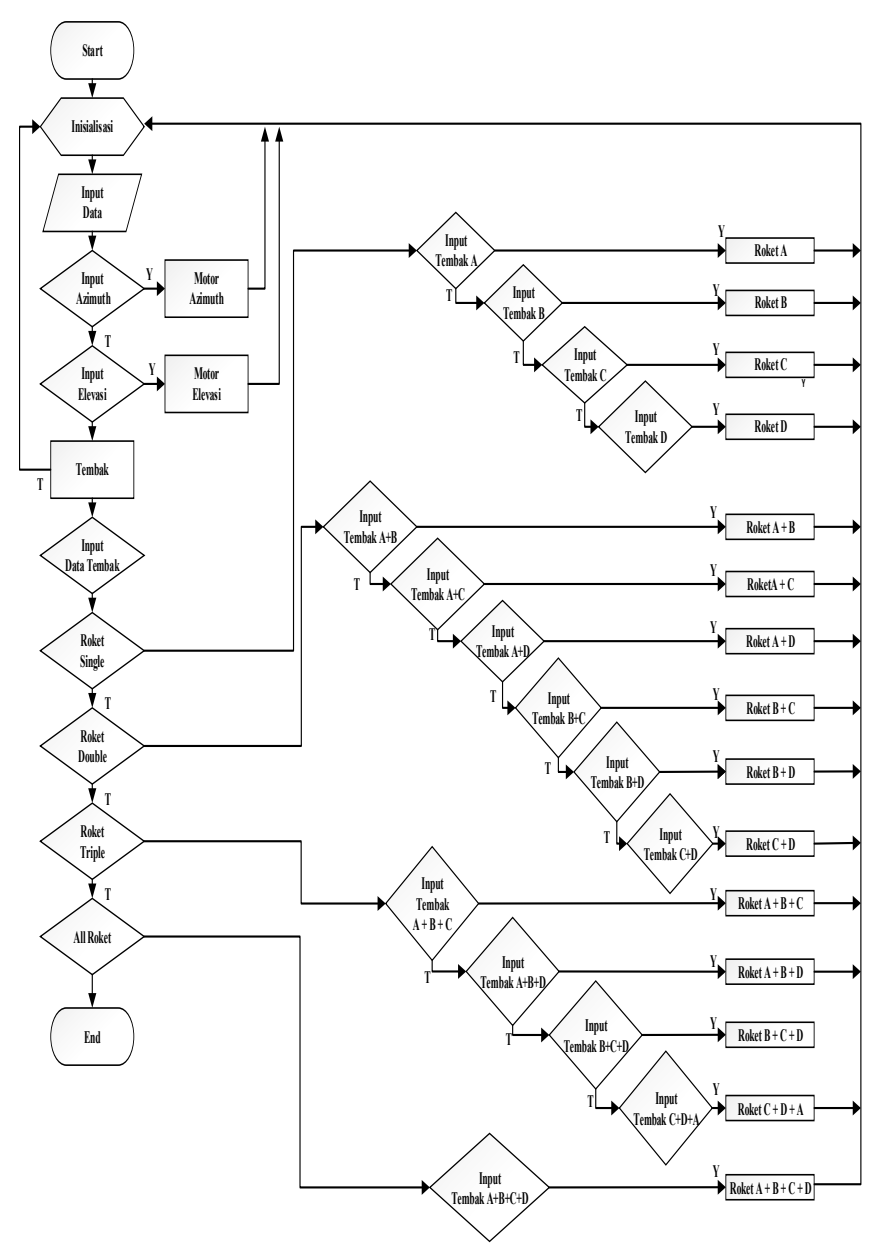

Fig. 3. Flowchart of Wheeled Robot with Rocket Launcher 


\section{RESULTS}

\section{A. Exploration}

The working system of this tool starts from the command sent by the laptop (PC) then sent to the microcontroller and converted to Xbee-pro, from the Xbee-pro frequency transmitted through the sender's Xbee-pro and received by the Xbee-pro receiver. Exbee-pro functions to convert signal waves into a voltage that will be received by the microcontroller, then the microcontroller executes the program according to the desired work system. The rocket launcher is moved to the azimuth and elevation angle to adjust the desired position, then the rocket is activated.

When pressing the button that functions as a switch, the trigger voltage will flow as the input voltage for the microcontroller. With the input voltage, the microcontroller will execute program commands to activate the active low (logic 0 ) on port PC4 and active high (logic 1) on the microcontroller PC5 port. PB1 will activate the PWM that enters the servo motor circuit. PWM is used to modulate the servo motor movement signal to move the elevation and azimuth angles. And to do the shooting, it will activate the microcontroller on the PC0, PC1, $\mathrm{PC} 2$, and $\mathrm{PC} 3$ ports.

\section{B. Motor Driver Testing}

In this test, if the PWM is set on each small motor, the motor speed will also be proportional to the PWM. However, for each movement the robot uses a different PWM value. If the robot moves to the left, the PWM on the right motor will be enlarged and the PWM on the left motor will be reduced but not 0 . This is done to prevent delays in response to the motor when changing polarity suddenly.

TABLE I. MOTOR Driver Test RESUlts

\begin{tabular}{cc}
\hline PWM & Output \\
\hline $19 \%$ duty cycle & $1.6 \mathrm{~V}$ \\
\hline $24 \%$ duty cycle & $2.8 \mathrm{~V}$ \\
\hline $27 \%$ duty cycle & $3.9 \mathrm{~V}$ \\
\hline $31 \%$ duty cycle & $4.8 \mathrm{~V}$ \\
\hline $39 \%$ duty cycle & $5.7 \mathrm{~V}$ \\
\hline
\end{tabular}

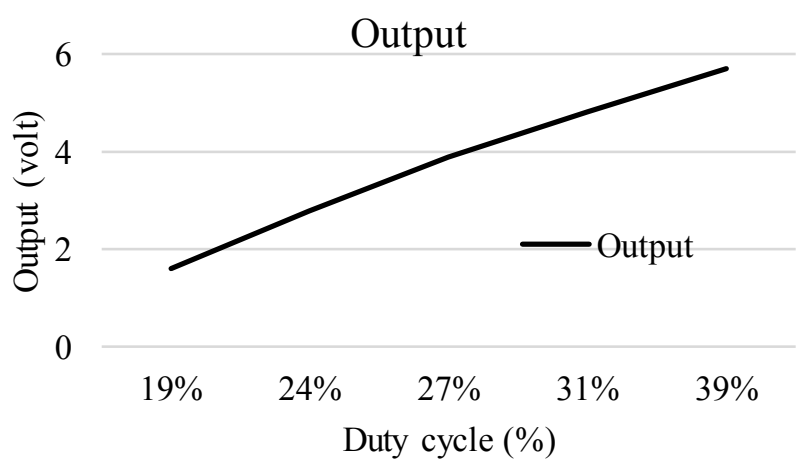

Fig. 4. Motor Driver test graph
From the results of the tests that have been done, it is found that if the data is made in a graph, the higher the PWM duty cycle used, the greater the output voltage applied to the motor, and the smaller the duty cycle, the smaller the output voltage

\section{Angle Position Accuracy Testing}

The potentiometer test data conducted shows that the potentiometer used has good linearity because the measurement results of the change in voltage to changes in resistance. So, it is ideal to be used as a detector for the position of the DC motor rotation angle in moving the rocket launcher to the angle of rotation that corresponds to the set point.

TABLE II. POTENTIOMETER SENSOR TEST DATA

\begin{tabular}{ccc}
\hline Corner & Resistance $\mathrm{K} \Omega$ & Voltage $(\mathrm{V})$ \\
\hline 10 & 2,56 & 1.73 \\
\hline 20 & 4,07 & 1.84 \\
\hline 30 & 5,45 & 1.36 \\
\hline
\end{tabular}

\section{Potentiometer Sensor test data}

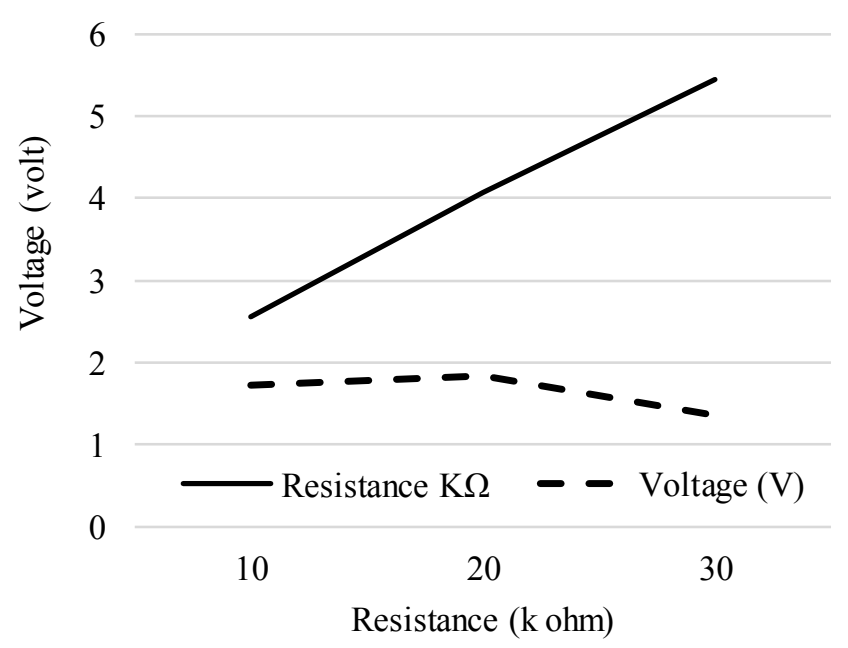

Fig. 5. Potentio sensor test graph

In testing the resistance value and voltage value when tested using a potentiometer, it is known that the greater the angle value, the greater the resistance value. In addition, in this test it can also be seen that the greater the angle value, the smaller the stress value, and the opposite is true.

TABLE III. TEST RESULTS AT AN ELEVATION ANGLE

\begin{tabular}{cc}
\hline Corner & Response (s) \\
\hline $0^{0}-10^{0}$ & 9.5 \\
\hline $10^{0}-20^{0}$ & 17 \\
\hline $20^{0}-30^{0}$ & 25 \\
\hline
\end{tabular}




\section{Test results at an elevation angle}

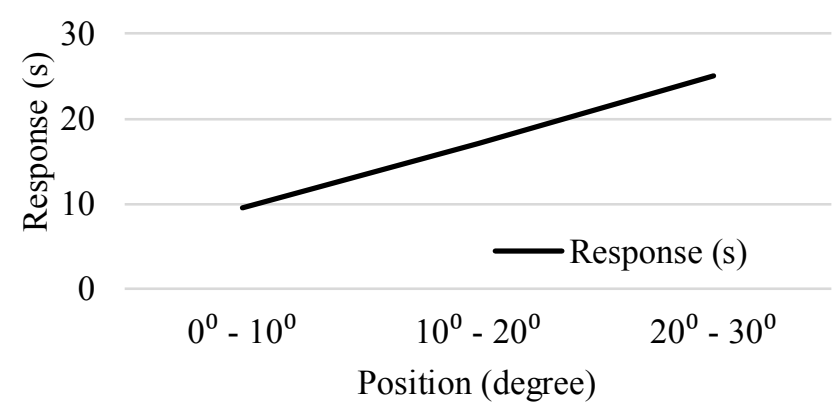

Fig. 6. Potentio sensor test graph

In the next test, it is carried out to determine the response of the movement of one angle to another. After testing, it is known that the greater the angle, the lower the response given.

TABLE IV. Test Results on the AzIMUth ANGLE

\begin{tabular}{cc}
\hline Corner & Response (s) \\
\hline $0^{0}-10^{0}$ & 7.5 \\
\hline $10^{0}-20^{0}$ & 19 \\
\hline $20^{0}-30^{0}$ & 27 \\
\hline
\end{tabular}

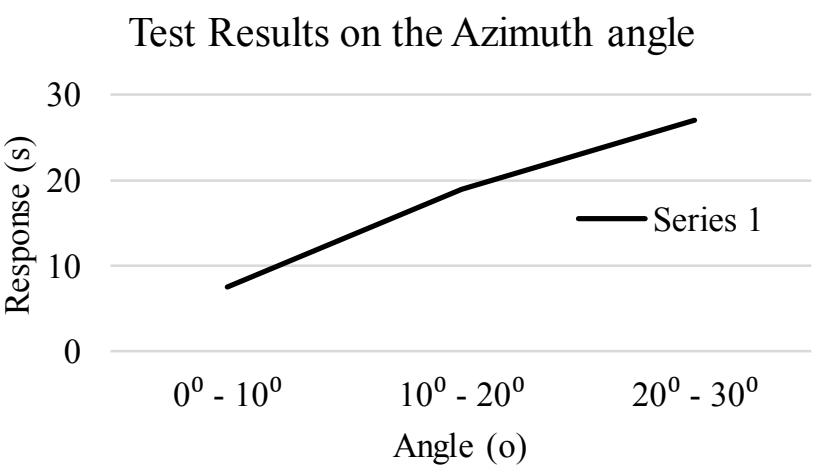

Fig. 7. Azimuth angle ters test graph

In testing the azimuth angle, it can be seen that the larger the angle, the slower the response will be and vice versa.

\section{Discussion}

The operation of the self-propelled anti-aircraft assembly is subjected to the comfort of the missile taking off from the launcher. The missile has a stiff connection to the guide before it is launched. The way it is attached makes it impossible for the missile to move towards the guide. The missile shell is in the shape of a cylinder, on which two guiding rings are housed. It is inserted into the tube guide with a certain interference. It means that the kinematic pair missile guide forms a specific type of fit. The missile touches the launcher guide with the guiding rings. It is between the rings and the inner wall of the guide that the slide connection is formed. The precision of the manufactured units under discussion guarantees the correctness of relative motion allowed by the structure of the discussed kinematic pair. The takeoff engine, whose aim is to set the proper linear and angular missile velocity, is in the rear part of the shell. Therefore, the missile on the launcher moves along the guide and at the same time round the longitudinal axis. The angular and linear relocation is realized in an unambiguously defined way.

From the results of the tests that have been done, it is found that if the data is made in a graph, the higher the PWM duty cycle used, the greater the output voltage applied to the motor, and the smaller the duty cycle, the smaller the output voltage.

In testing the resistance value and voltage value when tested using a potentiometer, it is known that the greater the angle value, the greater the resistance value. Besides that, in this test it can also be seen that the greater the angle value, the smaller the stress value, and the opposite is true.

In the next test, it is carried out to determine the response of the movement of one angle to another. After testing, it is known that the greater the angle, the lower the response given.

In the course of missile motion along the guide the guiding rings guarantee collinearity of the points located on the missile longitudinal axis with relation to the points located on the longitudinal axis of the guide. It is assumed that after leaving the guide by one of the guiding rings the collinearity is also present. The system structure results from the accepted geometrical assumptions and determines the kinematic possibilities of the missile towards its mobility.

\section{CONCLUSION}

From several experiments conducted, it can be concluded that the robot is able to go to the object determined by testing the accuracy of the rocket launch in the Azimuth angle of movement speed of $0^{\circ}$ to $30^{\circ}$ and the elevation angle of $0^{\circ}$ to $30^{\circ}$, the accuracy of the launcher position accuracy is as expected, $<4 \%$ or $=0 \%$.

\section{REFERENCES}

[1] Nugraha, Anggara Trisna. "Tracking Quadcopter Menggunakan Metode Command-Generator Tracker Dengan Efek Integrator." Jurnal Teknologi Elektro 8.2.

[2] Nugraha, Anggara Trisna. "ROBOT PENGURAI ASAP DALAM RUANGAN MENGGUNAKAN T-BOX DENGAN METODE BEHAVIOUR BASED CONTROL." Prosiding SENIATI (2017): B10-1.

[3] Nugraha, A. T., and T. Agustinah. "Quadcopter Path Following Control Design Using Output Feedback with Command Generator Tracker LOS Based At Square Path." Journal of Physics: Conference Series. Vol. 947. No. 1. IOP Publishing, 2018.

[4] Nugraha, Anggara Trisna. "DISTURBANCE REJECTION BERBASIS LOS SAAT TRACKING PADA JALUR LINGKARAN MENGGUNAKAN QUADCOPTER." Prosiding SENIATI (2018): 50 56.

[5] Nugraha, Anggara Trisna. "DIRTY AIR FILTER SYSTEM USING BOXED EQUALIZER MQ-8 AND MQ-9 WHEELED ROBOT." JEEMECS (Journal of Electrical Engineering, Mechatronic and Computer Science) 1.1 (2018): 23-26. 
[6] Nugraha, A. T., I. Anshory, and R. Rahim. "Effect of alpha value change on thrust quadcopter Qball-X4 stability testing using backstepping control." MS\&E 434.1 (2018): 012207.

[7] Nugraha, Anggara Trisna. "Rancang Bangun Teknologi Pemurni Air." Skripsi. Universitas Jember, Jember.[Diakses tanggal 27 Maret 2016-16: 18 WIB] (2015).

[8] Nugraha, Anggara Trisna, and Trihastuti Agustinah. "Quadcopter path following control design using output feedback with command generator tracker based on LOS." 2017 International Seminar on Intelligent Technology and Its Applications (ISITIA). IEEE, 2017.

[9] Nugraha, Anggara Trisna. Desain Kontrol Path Following Quadcopter Dengan Command Generator Tracker Model Following. Diss. Institut Teknologi Sepuluh Nopember, 2017.

[10] Nugraha, Anggara Trisna. "Desain Kontrol Path Following Quadcopter Dengan Algoritma Line of Sight." Prosiding SENIATI (2017): B9-1. 